Journal of Applied Veterinary Sciences, 4(1): 13-17 (2019).

ISSN: online; 2090-3308, print: 1687-4072

Journal homepage : https://javs.journals.ekb.eg

\title{
PROPAGATION, PURIFICATION AND MOLECULAR CHARACTERIZATION OF RVF VIRUS (ZH 501) STRAIN FOR VACCINE PRODUCTION IN EGYPT
}

\author{
Abo Hatab, E. M., ${ }^{1}$ M, H Ali, ${ }^{1}$ Atwa, M. H., ${ }^{2}$ Abul Magd, D.M., ${ }^{2}$ Ahmed F. Soudy ${ }^{2 *}$ and \\ Saad A. Moussa ${ }^{1}$ \\ ${ }^{1}$ Animal Health Research Institute, Dokki, Giza, Egypt \\ ${ }^{2}$ Veterinary Serum and Vaccine Research Institute, Abassia, Cairo, Egypt. \\ "Corresponding author: Ahmed F. Soudy; email: ahmed_saudy82@yahoo.com
}

\begin{abstract}
Rift Valley Fever (RVF) is an endemic disease in Egypt causing disease in animals and humans since the 1977. Full molecular description of the national vaccine strain is a strategic concern to ensure the antigenic makeup of local vaccine is adequate to provide the required protective immunity for the vaccinated animal species and as a tool of final product quality control. Molecular characterization and phylogenetic analysis of Gc gene of $\mathrm{M}$ segment of RVF-ZH501 strain which used in local vaccine production in veterinary serum and vaccine research institute (VSVRI) were carried out in this study. RVF-ZH501 strain was propagated by passages on BHK cell line and then purified my plaque purification technique. RT-PCR for amplification of the Gc gene of M segment. Sequence analysis of the obtained PCR product carried out by MEGA7 program. The result of the study revealed that RVF strain ZH501 Gc genomic content has $99.5 \%$ molecular identity to the strains firstly isolated in Egypt in 1977, so still suitable for vaccine production.
\end{abstract}

Original Article:

DOI: $\underline{\text { https://dx.doi.org/10.21608/javs.2019.62672 }}$

\section{Received 09 February, 2019. \\ Accepted 26 March, 2019. \\ Published in April, 2019.}

This is an open access article under the term of the Creative Commons Attribution 4.0 (CC-BY) International License . To view a copy of this license, visit http://creativecommons.org/licenses/by/4.0/

Keywords: Classical bursa , ELISA, IBD, inactivated vaccine, isolates of SNT.

J. Appl. Vet. Sci., 4(1): 13-17.

\section{INTRODUCTION}

Rift Vally Fever Virus (RVFV is the causative agent of Rift Valley fever(RVF), a zoonotic disease affecting both ruminants and humans. In ruminants, RVF is characterized by neonatal mortality and an increased incidence of abortion or foetal malformation (Ikegami and Makino, 2011). Sheep are the species of domestic animal most susceptible to RVFV infection and newborn lambs in particular (Daubney, et al., 1931). Mortality rate is significantly influenced by the age of the animal; newborn lambs are highly susceptible, with a mortality rate of greater than $90 \%$ in lambs less than a week old, associated with acute necrotic hepatitis (Gerrard, and Nichol, 2007). However, the mortality rate in adult ruminants is generally lower, at $10-30 \%$. The abortion rate can range between 40 and 100\% (Bird et al., 2009).

Rift Vally Fever Virus (RVFV is a mosquitoborne virus of the genus Phlebovirus, family Bunyaviridae (Schmaljohn and Nichol , 2007). The RVFV genome is composed of three segments of single-stranded RNA, referred to as large
(L), medium (M) and small (S) (Ikegami and Makino, 2011). The $\mathrm{L}$ segment encodes the viral RNA-dependent RNA polymerase (L protein) (Vialat et al., 2000 and Müller et al., 1994). The $\mathrm{S}$ segment encodes the nucleoprotein $(\mathrm{N})$ and the non-structural NSs protein, which is a major determinant of virulence (Bouloy et al., 2001). The M segment encodes at least four proteins: the structural glycoproteins $\mathrm{Gn}$ and $\mathrm{Gc}$, the non-structural protein Nsm, and a large $78-\mathrm{kDa}$ glycoprotein (LGp) (Weingartl; et al., 2014). Because of its potential to cause severe disease in both animals and man during outbreaks, RVFV is considered a major zoonotic threat which is classified as a category A overlap select agent by the Centre for Disease Control (CDC) and as a high-consequence pathogen with potential for international spread (List A) by the World Organization for Animal Health (Office International des Epizootics) (OIE, 2008).

During the first Egyptian RVF outbreak at 1977, a viral isolate designated as ZH501 strain, was isolated from a human case in Zagazig, Sharqia province, Egypt. This virus strain was used for 
preparation of a safe and potent inactivated RVF vaccine at Veterinary Serum and Vaccine Research Institute (VSVRI), Cairo, Egypt (Cooper, 1961). Due to the availability and abundance of the potential vectors, suitability of environmental conditions, continuous importation of livestock's from Sudan, and the close association of susceptible domestic animals with humans, the RVF virus could possibly occur and circulate in Egypt (Mohamed et al., 2018). These study aims to understanding interrelationship between RVFV stoke used in vaccine production and the different isolates worldwide including wild-type ZH501 strain, for improving vaccine quality and potency.

\section{MATERIALS AND METHODS}

\section{Virus and cells}

Rift Vally Fever Virus (RVFV) strain used in the study (ZH501) was supplied by VSVRI, Cairo, Egypt. After initial passaging in suckling mice, the ZH501 strain stock was generated and titrated on BHK-21 cell line. The virus used in this study has titre of $10^{8} \mathrm{TCID}_{50} / \mathrm{ml}$. MEM (Sigma, St. Louis, Mo, USA) containing $2 \%$ fetal bovine serum; FBS (Gibco BRL, Grand Island, NY, USA) are used.

\section{Plaque assay}

Selection of the different RVFV phenotypes was carried out using plaque assay as described by (Morrill JC, et al., 2010)[19]. The different developed plaques particularly those large in size, were selected, propagated in BHK-21 cells and designated RVFV ZH-501-2018.

\section{RNA extraction}

Extraction of genomic RNA using Gene JET $^{\mathrm{TM}}$ RNA Purification Kit, Fermentas LIFE SCIENCES, Canada. It was done according to the manufacture's protocol.

\section{RT-PCR and DNA sequencing}

The viral RNA $(5 \quad \mu l)$ was reverse transcriptase (RT)-PCR amplified using Access quick one-step RT-PCR kit (Promega, Madison, USA). The target Gc gene of $\mathrm{M}$ segment was amplified using primers created on Primer3 plus software and checked in blast, RVFVF: 5'TGTGCACACGTATCTGCAGT -3' and RVFVR: 5'- AAGAAGGCGGCATCACAAGA-3'. The optimized cycling conditions were: 1 cycle at $45^{\circ} \mathrm{C}$ for $30 \mathrm{sec}$; 1 cycle at $94^{\circ} \mathrm{C}$ for $5 \mathrm{~min}$; 40 cycles of $\left(94^{\circ} \mathrm{C}\right.$ for 30 seconds, $55^{\circ} \mathrm{C}$ for 30 seconds and $72^{\circ} \mathrm{C}$ for $1 \mathrm{~min}$ ), and finally 1 cycle at $72^{\circ} \mathrm{C}$ for $10 \mathrm{~min}$. The RT-PCR products were analyzed in $1.25 \%$ agarose gel containing $0.5 \mu \mathrm{g} / \mathrm{ml}$ ethidium bromide. Specific bands were excised from the gel and purified using Montáge DNA gel extraction kit (Millipore,
Concord Road Billerica, MA, USA). The purified PCR product were sequenced using ABI Big-Dye 3.1 dye chemistry and ABI 3110 Prism automated DNA Genetic Analyzer (Applied Biosystems, Foster City, CA, USA).

\section{Phylogenetic Analysis.}

Nucleotide and amino acid sequences were evaluated in MEGA $\mathrm{X}$ software program and Phylogenetic tree based on sequences constructed by the Maximum Likelihood method of MEGA-X fig. 1.

\section{RESULTS}

\section{Virus plaque assay}

RVFZH501-2018 strain was propagated and titrated in BHK-21 cells in order to obtain large amount of concentrated virus, Virus titer increased gradually from $1^{\text {st }}$ passage $\left(10^{7.5}\right.$ TCID50/0.1ml) $3^{\text {rd }}$ passage of $(10$ ${ }^{8}$ TCID50 $/ 0.1 \mathrm{ml}$ ) with $0.5 \log 10$ as mean difference, also the virus was titrated in mice by evaluating the lethal dose fifty percent $\left(\mathrm{LD}_{\mathbf{5 0}}\right)$, and the virus titer was $10^{7.4}$ MIPLD50 /0.2ml.

\section{Sequence analysis of RVFV ZH-501- 2018 Gc gene \\ Sequencing of RT-PCR product of Gc gene} was conducted in both direction, and a consensus sequence of about 568 bp was used for nucleotide and deduced amino acid analysis. The sequence data was submitted to the GenBank and has obtained the accession number MH 910494. Sequence analysis of ZH-501-2018, in comparison to the reference strains (Table 1), revealed a high degree of sequence homology (similarity) with strains $\{\mathrm{ZH}-501-177, \mathrm{~T} 1$, ZH-501, T-46 (228113), 1853/78, ANK-3837, SAUDI 200010901, SUDAN 2V-2007, M48/08\} about (99.48) (table 2).

Table 1: reference RVF strains obtained from gen bank which used for comparison:

\begin{tabular}{|c|c|c|l|}
\hline No. & Country & $\begin{array}{c}\text { Isolate } \\
\text { designation }\end{array}$ & Accession Number \\
\hline 1 & Egypt & $\begin{array}{c}\text { ZH-501- } \\
2018\end{array}$ & MH910494 \\
\hline 2 & Egypt & $\begin{array}{c}\text { ZH-501- } \\
777\end{array}$ & gi|87622795|DQ380202.1 \\
\hline 3 & Egypt & T1 & gi|87622793|DQ380201.1 \\
\hline 4 & Egypt & ZH-501 & gi|87622791|DQ380200.1 \\
\hline 5 & Egypt & $\begin{array}{c}\text { T-46 } \\
(228113)\end{array}$ & gi|87622789|DQ380199.1 \\
\hline 6 & Zimbabwe & $1853 / 78$ & gi|87622831|DQ380220.1 \\
\hline 7 & Guinea & ANK-3837 & gi|87622821|DQ380215.1 \\
\hline 8 & $\begin{array}{c}\text { Saudi } \\
\text { Arabia }\end{array}$ & $\begin{array}{c}\text { SAUDI } \\
200010901\end{array}$ & gi|1020216136|KU978778.1 \\
\hline 9 & Sudan & $\begin{array}{c}\text { Sudan 2V- } \\
2007\end{array}$ & gi|433287033|JQ820490.1 \\
\hline 10 & Madagascar & M48/08 & gi|332157193|HQ009512.1 \\
\hline
\end{tabular}


Ahmed F. Soudy et al.

Table 2: Estimates of Evolutionary Divergence between Sequences.

\begin{tabular}{|l|l|l|l|l|l|l|l|l|l|}
\hline ZH-501-2018 & & & & & & & & & \\
\hline RVF_ZH-501-777 & 0.23 & & & & & & & & \\
\hline RVF_T1. & 0.23 & 0.00 & & & & & & & \\
\hline RVF_ZH-501. & 0.23 & 0.00 & 0.00 & & & & & & \\
\hline RVF_T-46_(228113). & 0.23 & 0.00 & 0.00 & 0.00 & & & & & \\
\hline RVF1853/78. & 0.23 & 0.01 & 0.01 & 0.01 & 0.01 & & & & \\
\hline RVFANK-3837. & 0.24 & 0.02 & 0.02 & 0.02 & 0.02 & 0.01 & & & \\
\hline SAUDI_200010901. & 0.24 & 0.03 & 0.03 & 0.03 & 0.03 & 0.02 & 0.03 & & \\
\hline Sudan_2V-2007. & 0.23 & 0.02 & 0.02 & 0.02 & 0.02 & 0.02 & 0.03 & 0.02 & \\
\hline RVF_M48/08. & 0.23 & 0.02 & 0.02 & 0.02 & 0.02 & 0.01 & 0.02 & 0.02 & 0.01 \\
\hline
\end{tabular}

Table 3: Evolutionary divergence \& Protein analysis of RVFV ZH-501-2018 Gc protein.

\begin{tabular}{|l|l|l|l|l|l|l|l|l|l|}
\hline ZH-501-2018 & & & & & & & & & \\
\hline RVF_ZH-501-777 & 0.23 & & & & & & & & \\
\hline RVF_T1. & 0.23 & 0.00 & & & & & & & \\
\hline RVF_ZH-501. & 0.23 & 0.00 & 0.00 & & & & & & \\
\hline RVF_T-46_(228113). & 0.23 & 0.00 & 0.00 & 0.00 & & & & & \\
\hline RVF1853/78. & 0.23 & 0.01 & 0.01 & 0.01 & 0.01 & & & & \\
\hline RVFANK-3837. & 0.24 & 0.02 & 0.02 & 0.02 & 0.02 & 0.01 & & & \\
\hline SAUDI_200010901. & 0.24 & 0.03 & 0.03 & 0.03 & 0.03 & 0.02 & 0.03 & & \\
\hline Sudan_2V-2007. & 0.23 & 0.02 & 0.02 & 0.02 & 0.02 & 0.02 & 0.03 & 0.02 & \\
\hline RVF_M48/08. & 0.23 & 0.02 & 0.02 & 0.02 & 0.02 & 0.01 & 0.02 & 0.02 & 0.01 \\
\hline
\end{tabular}

Fig. 1: Phylogenetic tree of nucleotides of Gc of ZH501-2018 and other reference strains of RVF .

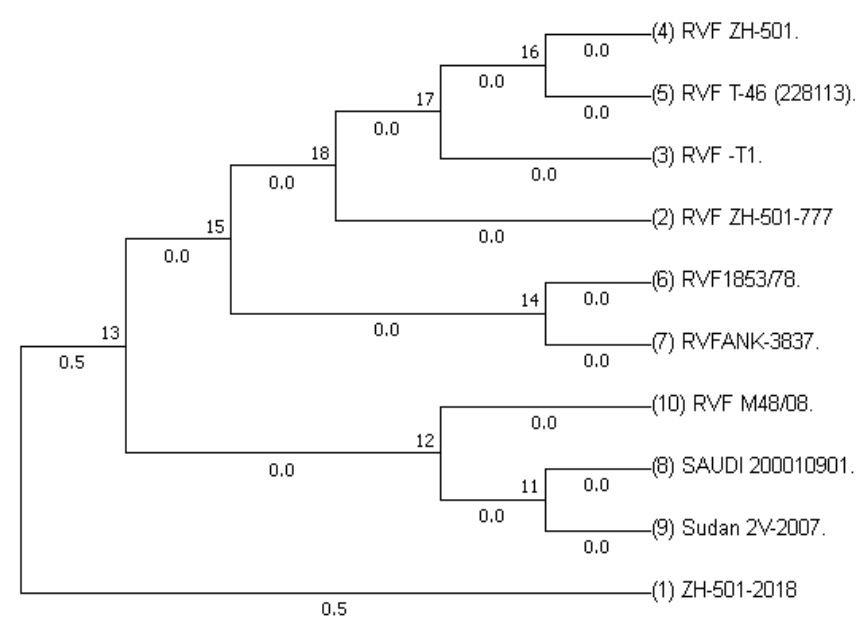

By Maximum Likelihood method
Fig. 2: Molecular Phylogenetic tree of deduced amino acids of Gc of ZH501- 2018 and other reference strains

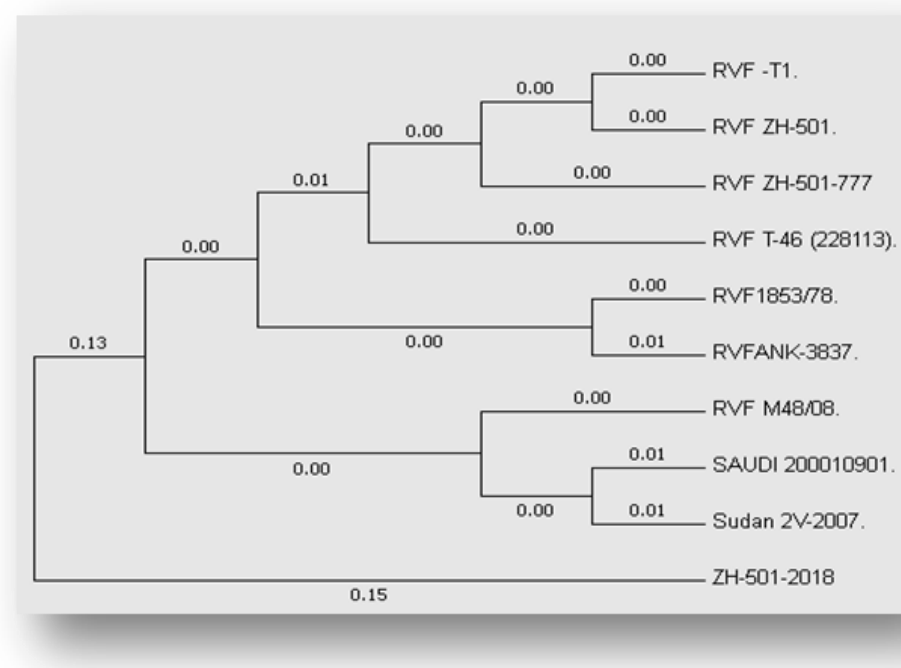

By Maximum Likelihood method 
The numbers of base differences per site sequences are shown. The analysis involved 10 nucleotide sequences. All positions containing gaps and missing data were eliminated. There were a total of $568 \mathrm{bp}$ positions in the final dataset.

\section{Protein analysis of RVFV ZH-501-2018 Gc protein}

The number of amino acid differences per site from between sequences are shown. The analysis involved 10 amino acid sequences. All positions containing gaps and missing data were eliminated. There were a total of 568 positions in the final dataset. Evolutionary analyses were conducted in MEGA7 (20) (table 3).

\section{DISCUSSION}

RVFV has demonstrated ability for emerging and reemerging in new territories after long periods of silence, the high viral titers in viraemic animals and the global changes in climate, travel and trade all makes this virus a bio threat for human and animal health (OIE, 2014). Vaccine preparation using attenuated MP12 obtained from the virulent Egyptian strain (ZH548) after random mutagenesis with 5fluorouracil mutagen (Pepin et al., 2010). This virus acquired mutations in all three segments and had lost its virulence when tested in mice (Caplen $\boldsymbol{e t}$ al., 1985). Moreover, it was shown to induce a good immunity in ruminants after experimental inoculation (Vialat et al., 1997).

In Egypt tissue culture passed inactivated aluminum hydroxide gel RVFV vaccines prepared from ZH501 virulent strain are commonly used (EL Nimr 1980). Molecular characterize of the vaccinal strain of RVFV to ensure adequacy of the vaccine to provide the required level of vaccinal protection and to make sure that the vaccine does not contain other than the vaccine seed virus.

Our first task was to provide evidence that vaccine strain is a homogenous mix of viruses capable of producing uniform size plaques. However, plaque assay showed only that the vaccine strain contained RVFV that produced at least two plaque sizes. The larger and more abundant of the plaques (resembled those produced by the wild-type ZH501) were picked. The smaller minute size plaques were not selected. Changes in plaque size (phenotype) have been reported for RVFV (Morrill et al., 1997). Multiple plaque purification of the virus stock doesn't prevent the development of small size plaques (OIE, 2008). Nucleotide sequence-based phylogenetic analysis revealed that ZH501 VSVRI are clustered with the Egyptian viruses reported in the first outbreak Fig. (1). This is a strong indication that it is very suitable virus for vaccine production in Egypt. It will also be a very valuable tool for the identification of whether outbreaks were caused by improper inactivation of the virus during vaccine manufacture. Bovine and human RVFV strains isolated in later years from other Arabian and African countries and those used in this comparative analysis, including the Saudi_2000- 10901 and Sudan 2V-2007, showed that, these strains were clustered away from the ZH5012018. We can conclude that none of the recent outbreaks were caused by the parent virus from which the vaccine virus was isolated or ZH501-2018 itself. This means that the national Egyptian vaccine is exonerated from the most recent outbreaks in Egypt.

\section{CONCLUSION}

It is recommended that we continue to fingerprint the remaining segments of the ZH501-2018 together with circulating strains of the virus to continue to confirm that it remains the ideal vaccinal strain for current circulating RVFV strains. Finally, we can conclude that, the Egyptian strain of ZH501-2018 carries several characters make it suitable for vaccine preparation in extended period of time, its genomic make up is stable with low molecular diversity and low tolerance for mutations. ZH501-2018 is more advantageous than other strains in vaccine production.

\section{Declaration of Competing interest}

On behalf of all authors, I hereby declare that no conflict of interest may interfere with the publication of the manuscript.

\section{REFERENCES}

BIRD, B.H; T.G. KSIAZEK, S.T. NICHOL, N.J. MACL ACHLAN. 2009. Rift Valley fever virus. J Am Vet Med Assoc, 234 (2009), pp. 883-893.

CAPLEN, H.; PETERS, C.J. AND BISHOP, D.H. 1985. Mutagendirected attenuation of Rift Valley fever virus as a method for vaccine development. J Gen Virol; 66 (10):2271-7.

COOPER PD.1961. The plaque assay of animal viruses. Adv. Virus Res.;8:319-378.

EL-NIMR. M.M. 1980. Studies on the inactivated vaccine against Rift Valley Fever. PhD Thesis, Fac Vet Med, Assuit Univ, Egypt.

WEINGARTL,H.M. , S. ZHANG, P. MARSZAL, A. MC GREEVY. BURTON. 2014. Rift Valley fever virus incorporates the $78 \mathrm{kDa}$ glycoprotein into virions matured in mosquito C6/36 cells. PLoS ONE, 9 (2014), p. e87385.

IKEGAMI, T, AND MAKINO, S. .2011. The pathogenesis of Rift Valley fever Viruses, 3 (2011), pp. 493-519.

BOULOY, M;C. JANZEN, P. VIALAT, H. KHUN, J. P AVLOVIC, M. HUERRE. 2001. Genetic evidence for an interferon-antagonistic function of Rift Valley 
fever virus non-structural protein NSs. J Virol, 75 (2001), pp. 1371-1377.

MOHAMED A.KENAWY ${ }^{A}$ YOUSRYA M. ABDELHAMID $^{\mathrm{B}}$ JOHN C.B EIER ${ }^{\mathrm{C}}$.2018. Rift Valley Fever in Egypt and other African countries: Historical review, recent outbreaks and possibility of disease occurrence in Egypt. Acta Tropica. Volume 181, May 2018, Pages 40-49.

MORRILL JC, IKEGAMI T, YOSHIKAWA-IWATA N, LOKUGAMAGE N, WON S, ET AL. 2010. Rapid accumulation of virulent Rift Valley fever virus in mice from an attenuated virus carrying nucleotide substitution in the M RNA. PLos One 5: e9986.

MORRILL, J. C.; MEBUS, C. A. AND PETERS, C. J. 1997. Safety of a mutagen-attenuated Rift Valley fever virus vaccine in fetal and neonatal bovids. Am J Vet Res.; 58(10):1110-4.

MÜLLER. R, POCH. O, DELARUE. M, BISHOP. D.H.L, BOULOY. M. 1994. Rift Valley fever virus L segment: correction of the sequence and possible functional role of newly identified regions conserved in RNA-dependent polymerases. J Gen Virol, 75 (1994), pp. 1345-1352.

OIE. 2008. Rift Valley Fever Terrestrial Manual 2.1.14. Available http://www.oie.int/Eng/Normes/Mmanual/2008/. Accessed on 3rd June 2011.

OIE TERRESTRIAL MANUAL, . 2014. Rift Valley Fever, chapter 2.1.14. May 2014.

PEPIN, M.; BOULOY, M.; BIRD, B.H.; KEMP, A. AND PAWESKA, J. .2010. Rift Valley Fever virus (Bunyaviridae: Phlebovirus): an update on pathogenesis, molecular, epidemiology, vectors, diagnostics and prevention.Veterinary Research 41, 61.

DAUBNEY, R; J.R. HUDSON, P.C. GARNHAM .1931. Enzootic hepatitis or Rift Valley fever. An undescribed virus disease of sheep, cattle and man from East Africa. J Pathol Bacteriol, 34 (1931), pp. 545-549.

GERRARD, S.R. AND S.T. NICHOL 2007. Synthesis, proteolytic processing and complex formation of $\mathrm{N}$ terminally nested precursor proteins of the Rift Valley fever virus glycoproteins. Virology, 357 (2007), pp. 124-133.

SCHMALJOHN C.S., and NICHOL S.T. 2007. Bunyaviridae, Fields virology (5th ed.), Lippincott, Williams and Wilkins, Philadelphia, PA (2007), pp. 1741-1789.

VIALAT, P, A. BILLECOCQ, A. KOHL, M. BOULOY, 2000. The segment of Rift Valley fever phlebovirus (Bunyaviridae) carries determinants for attenuation and virulence in mice. J Virol, 74 (2000), pp. 15381543.

VIALAT, P.; MULLER, R.; VU, T. H.; PREHAUD, C. AND BOULOY, M. 1997. Mapping of the mutations present in the genome of the Rift Valley fever virus attenuated MP12 strain and their putative role in attenuation. Virus Res. 52(1):43-50.
How to cite this article:

Abo Hatab E. M., M. H. Ali; Atwa M. H., Abul Magd D.M., Ahmed F. Soudy and Saad A. Moussa,2019. Propagation, Purification and Molecular Characterization of RVF Virus $(\mathrm{ZH}$ 501) Strain for Vaccine Production in Egypt. Journal of Applied Veterinary Sciences, 4(1): 13- 17. DOI : https://dx.doi.org/10.21608/javs.2019.62672 